\title{
North Sea Investigations.
}

\author{
(Continued.)
}

\section{By}

\section{Ernest W. L. Holt,}

Naturalist on Staff in charge of Investigations.

I. On the Relation of Size to Sexual Maturity in Pleuronectids
II. On the Destruction of Immature Fish in the North Sea
III. Remedial Measures .

I. On the Relation of Size to Sexdal Maturity in Pleuronectids.

Introductory.-I believe that, so far as concerns the more important species, sufficient information has been accumulated to allow of the deduction of a reliable conclusion.

Though it is certain that some local variation exists in the different parts of the North Sea, I have not found it possible to treat the area otherwise than as a single district. This is of the less importance since the variation seems to be very slight, and in any practical application of the results arrived at I do not see how it would be feasible to subdivide the district.

It again becomes my pleasing duty to acknowledge much courtesy and assistance in carrying out my work. Without the permission of owners to examine the larger and more valuable kinds of fish without purchasing them, my records would be indeed meagre. I shall not attempt to enumerate those who have helped me in this way, as the list would comprise almost every smack-owner or fish merchant in Grimsby. The greater part of the work has been carried on, by kind permission of the Marine Fisheries Society of Grimsby, at the Cleethorpes Hatchery.

Scheme of Work.-The scheme upon which my deductions are based requires little explanation, since I have seen no good reason to change the opinion which I have expressed in a report upon the same subject for a different district (Sci. Proc. R. Dubl. S., * vol. vii,

* Reprinted from the Report of the Council Royal Dubl. Soc. for 1891, Feb., 1892. 
pt. 4, 1892, p. 418), that any biological definition of mature and immature fish must depend upon the conditions of the larger sex, or, strictly speaking, upon the sex in which, as regards dimensions, maturity is most retarded. This sex is almost invariably the female.

But it must be borne in mind that when a ripe or nearly ripe fish is caught there is, and I think can be, no means of determining whether it is spawning for the first time or has spawned in previous years. Consequently observations made during or shortly before the spawning season yield results that are only entirely reliable for the time of year during which they were made-for this reason, that a fish which by a narrow margin was either too young or too small, or from whatever cause was unfitted to spawn last season, will have very materially increased in length before the present season. In this connection researches on the rate of growth are of the highest importance, and without a greater knowledge on that subject than we already possess, it is impossible to form reliable conclusions. Much, however, may be done by continuing the examination of the reproductive organs throughout the year.

I do not know whether it will ever be practicable to utilise the evidence afforded by such fish in formulating any size limit for practical use. In any case the season is not sufficiently advanced for their consideration, and therefore in the tables which are appended I have only dealt with fish taken during, shortly before, or shortly after the spawning season. I believe that the size limits deduced from these will be quite as high as any that are likely to be acceptable, and that they will be sufficiently efficacious for the upkeep of the species.

The term "immature" is used in this paper to denote that the reproductive organs show no sign of activity, and to the best of my knowledge have not subserved a reproductive function in previous years.

Method of distinguishing the Different Conditions.-I have studied the conditions of the female reproductive organ with much more attention than has been devoted to that of the male, since the larger size and numerical preponderance render the former sex infinitely the more important in the present connection. In the case of the male. I have relied chiefly on the external characters of the testis, viz. those of size, contour, and apparent consistency, since these seem to be sufficient for the purpose, except in the case of the sole, which has required more careful attention than the rest.

In the immature female, the ovary, so soon as it is large enough to be easily perceptible, is found to contain a number of minute translucent ova, their size and condition depending neither upon the season of the year nor upon the size of the fish. Thus there is no 
obvious difference in the ova of two plaice of five and ten inches respectively.

The first approach to maturity is denoted by an enlargement of some of the ova, and by various changes in their internal structure (well known to students of Teleostean embryology), of which we need notice only one. This is the assumption of an opaque condition $;^{*}$ and since it is the character which is most readily apparent, I have utilised it in separating ova which are approaching an individual participation in the reproduction of the species from such as either will or may be absorbed without ever ripening. The former, for the purposes of the present work, may be termed " active," and the latter "inactive" ova, without implying the actual difference denoted by the two words. Even before they are actually visible to the naked eye, the presence of "active" ova may be detected in a germinal epithelium by a change in the coloration and consistency of the latter. $\dagger$

$\mathrm{Mr}$. Cunningham, in the last number of this journal, p. 227, deplores the absence of any criterion by which one can find out whether a fish has spawned or not ; if the fish be not ripe or ripening when caught " it may be sexually immature, or it may have spawned previously, its sexual organs being merely in an inactive state at that particular time of the year."

To establish such a criterion has, of course, been an essential part of the present research; as a result, I am satisfied that the features upon which I myself, and I suppose most other observers, have been accustomed to base a diagnosis, are adequate for the purpose, provided a careful examination is possible.

I have met with no single character, nor even combination of several characters, which has a general applicability in this matter for Teleosteans as a whole. The variation in structure and disposition of the reproductive organ is so remarkable that a different treatment may be required even within the limits of a single genus.

As we are here dealing only with the flat-fishes, there is no need to advert to other forms, and I shall therefore confine myself to discussing the conditions in so far as they affect the former alone.

Undoubtedly the most important point is the distinction between immature and spent (and resting) fish.

The most important characters in distinguishing these stages may be enumerated, in the order in which they become apparent, as follows:

* The changes which give rise to the opaque condition are not the same in all species, but they occur at much the same stage of development, and appear to possess the same significance.

+ Specimens in which the ovaries exhibit the other characters of immaturity, but in which the largest ova are just passing from the "inactive" to the "active" condition, are included in the tables amongst the immature. 
(i) Size and appearance of ovary.

(ii) Topographical relationships of ovary.

(iii) Size and condition of living ova.

(iv) Presence of ripe ova which have failed to be extruded at the time of spawning.

Characters (i) and (ii) are essentially dependent on each other, and their interpretation varies with the species in a manner which I shall attempt to indicate below.

In the next character (iii) we have, I suppose, the clue to the difficulty in distinguishing immature and spent fish, since one may find, in the ovaries of a fish which from its large size might be supposed to have spawned at some previous time, only such "inactive" ova as I have described above. I have, however, never met with such a condition, during the spawning season, in any fish which might not, from its contiguity in size to a series of obviously immature examples, be reasonably supposed to illustrate the variation in the assumption of the mature state.

It is still too early in the season to ascertain whether a period of inactivity is a regular feature in the rhythm of ovarian development in all Pleuronectids, since some are still spawning, and others have only recently ceased to do so.

I have met with no such condition in the plaice, which is the earliest spawner of all (with the doubtful exception of the halibut, about which little is known), though I have made somewhat careful inquiries into the ovarian condition of that species since the end of the spawning season. Dabs, however, which presumably spawned about April, now* exhibit a germinal epithelium entirely destitute of active ova.

It need hardly be said that the last character (iv) is an infallible proof of previous spawning when it is present.

In all species which $I$ have studied a certain number of ripe ova fail to make their escape, and remain to decompose either in the lumen of the ovary itself or in the ovary duct. But their number, and the period during which their presence can be ascertained, appear to vary with the individual and also with the species. Thus I believe that they are most numerous and perceptible for the longest period in the plaice, perhaps because this species has the largest ova; and I have no doubt the lemon sole is the form in which this character gives us the least assistance. I have received a plaice with ovaries enormously distended with ripe, yet dead and slightly decomposed ova, and though outside pressure caused these to be extruded, it was evident that their deposition was beyond the power of the parent. 
That the ova of an individual female are not shed all at once, but in successive crops, is well known (cf. Fulton, Comparative Fecundity of Sea Fishes, Rep. S. F. B., 1891, p. 245), and I think that the different degrees in which the retention of ripe ova obtains in different species must be explained by the difference in the size of and interval between the several crops. In the plaice, and in some other species, a greater number of ova, compared to the capacity of the ovary, ripen together, and the successive crops appear to overlap each other to some extent, so that there never seems to be a time when some ova are not ready for extrusion. Consequently the muscular efforts for extrusion have the co-operation of the constant and rapid increase of the successional crops, so long as any such remain; but when it comes to the turn of the last crop the elasticity of the walls of the ovary and the muscular power of the parent are so insufficient that a comparatively large number fail to make their escape.

In the lemon sole, on the contrary, I have evidence that the crops are individually small (compared to the capacity of the ovary), and separated from each other by intervals which, though imperceptible in the spawning period of the species, must be well marked in individual parents. The fish must therefore possess resources, muscular or otherwise, which render it practically independent of the assistance afforded by the successional crops in extruding the ripe ova (the difficulty being lessened by the comparatively small number of the latter which are simultaneously ready), and thus does not encounter any unusual obstacle in disposing of the last crop.

Before dealing with the topographical features of the ovary in its different conditions we must briefly advert to the modifications exhibited in the disposition of the viscera in the various species.

As is well known, the ripe ovaries in any flat-fish are disposed on either side of the hæmal spines, and extend from a point in the neighbourhood of the bony buttress which forms the centre of the hind wall of the peritoneal cavity to a greater or less distance from the commencement of the caudal peduncle. A single ovary duct, formed by the coalescence of the duct from either ovary, follows the course of the buttress in its anterior curve to the genital orifice.

But while all have this much in common in the ripe condition, the British representatives of the family fall into two groups, based upon the arrangement of the alimentary canal and the shape of the reproductive organ :

(a) including the halibut, long rough dab, turbot, brill, megrim (scald-fish and topknots ?), plaice, flounder, and common dab.

In these no portion of the alimentary canal extends to any considerable distance beyond the first hæmal spine. The ovaries are NEW SERIES.-VOL. II, NO. IV. 
subequal in size, and markedly dilated dorso-ventrally in their anterior region. The kidney is situated in the roof of the peritoneal cavity, in front of the great hæmal spine, and the urocyst between the anterior ends of the ovaries and their ducts.

(b) including the lemon sole, the witch or pole dab, the common sole (and probably other members of the genus Solea).

In these a loop of the ileum passes back on the ocular* side of the hæmal spines for a greater or less distance (greatest in the sole, least in the witch). The ocular is consequently much smaller, having less space at its disposal, than the blind ovary, and neither is very markedly dorso-ventrally dilated in its anterior region. The excretory organs are as in group $(a)$ in the lemon sole and witch, but in the true sole the urocyst and the hinder part of the kidney pass back on the blind side of the anterior hæmal spines.

In immature fish of group (a) on removing the body-walls of the abdominal region on either side the free anterior portions of the ovary are seen to form, with the bony buttress, the hind wall of such part of the body-cavity as lodges the alimentary viscera. The one ovary is a little in front, the other a little behind the buttress, or both may be to some extent united in front of it. They appear as plump cushion-like structures, following the course of the buttress, rounded off near its origin, and tapering into the ovary ducts towards its distal extreme. Passing the finger backwards along the external surface of the fish no groove is perceptible, in fresh specimens, between the region of the vertebral column and that of the interhæmal bones. Dissecting away the anterior muscles of the caudal region, we find that each ovary is continued backwards for a short distance alongside of the hæmal spines in a tapering process terminating in a moderately fine point.

The length of the posterior process, as compared with the distance between the first hæmal spine and the caudal peduncle, varies with the species and with the size of the individual, but probably in no case exceeds one third, and is usually much less. The whole structure is very plump and firm, and is firmly embedded between the hæmal arches and the caudal muscles. If a seeker is pushed backwards in the direction of the posterior process a considerable amount of closely set connective tissue will be ruptured in its progress.

On cutting into the ovary its lumen is found to be entirely or nearly occluded by germinal epithelium, beset with inactive ova of various degrees of minuteness.

* The terms "ocular" and "blind" are used in this paper, since they are intelligible in connection with Pleuronectids, and, while eliminating the confusion between right and left in dealing with a mixture of dextral and sinistral forms, do not, as it were, outrage morphology like Fulton's qualified use of "dorsal" and "ventral," 
Now if we examine a spent female of the same group the conditions are very different. In the first place, the anterior or free region of the ovary is enlarged and flaccid; a distinct depression can be felt from the outside on either side of the hæmal spines, extending well-nigh to the caudal peduncle. On removing the muscular wall in this region we find the posterior process of the ovary much elongated, thin, and flaccid, and very loosely lodged between the spines and the muscles; whilst in the anterior region the connective tissue which formerly united the muscular and skeletal elements ventral to the front of the ovary may have to a great extent disappeared, so that a mesentery forms in this region the only boundary between what one may term the alimentary and reproductive portions of the visceral cavity. The length of the ovary is variable, but is seldom if ever less than half of that between the first hæmal spine and the caudal peduncle.

On opening the ovary the contents are found to vary according to the time which has elapsed since spawning. If the latter is recently over, the germinal epithelium shows traces of ruptured follicles, and more or fewer ripe and decomposing ova are to be met with; at this stage their nature will be at once obvious. In spent fish at any period which I know the lumen of the ovary is wide, and the germinal epithelium of the posterior process is arranged in conspicuous longitudinal ridges. It may contain, as in all plaice which I have examined, a number of small "active" ova, in addition to a host of "inactive" ones, but I am uncertain whether these represent the early condition of next season's crop, or only ova which, though they pass the inactive stage, are absorbed without ever reaching a considerable size. It appears most probable that after spawning the ovary continues for some time to produce a certain number of active ova, which, however, are successively absorbed, without ripening, until the approach of the next season. Otherwise it is necessary to suppose that an ovum in this species, and others which in this respect agree with it, takes the best part of a year to ripen after it has passed the "inactive" condition.

The dab is so far the only form in which $I$ have found only inactive ova in the germinal epithelium of spent ovaries.

Of a number of females examined in August the ovaries of most exhibited the features which I have just described as characteristic of spent fish, but in three the characteristics were those of immature fish. There was no difference whatever in the ova in the germinal epithelium, but on instituting a careful search certain whitish gelatinous bodies were met with in the ovary ducts of some of the larger fish. These proved to be the remnants of ripe ova, the zona being the most recognisable feature. There could be no doubt that 
the fish which contained such bodies had spawned, and it was reasonable to suppose that those which showed no traces of retained ova had either spawned a little earlier or had lost these substances a little sooner than the rest. The chief question is whether the fish which agreed with my ideas of immaturity might not really represent a further stage in a period of inactivity after spawning. We know that when the ovary ripens for the first time its posterior process forces its way backwards between the caudal muscles and hæmal spines towards the tail, thus attaining the elongation which is familiar in the ripe condition. When the ova have been discharged the elasticity of the ovary walls causes a considerable shrinkage, apparently at once; so that a recently spent ovary is always shorter than one full of ripe ova, as well as much narrower. It may be suggested that this process of shrinking is continued until the ovary has reached the proportions and shape of an immature example, the muscles and connective tissue also closing in on it. If this were so, there could be no possible way of distinguishing the spent from the immature condition apart from the presence of the remains of ripe ova of a former crop.

My evidence, however, points to the opposite conclusion, viz. that the ovary, once spent, never reverts to a condition resembling that of an immature fish. The fish I have referred to were nine in number, and consisted of seven, diagnosed as spent, from $10 \frac{3}{4}$ to $14 \frac{1}{2}$ inches; the three apparently immature forms measuring 11 , $11 \frac{3}{4}$, and 12 inches respectively. Now, speaking as a general rule, it is the largest fish of a species which spawn the earliest; and since the ovary after spawning must needs pass through the widewalled flaccid condition, with traces of retained ova, before it could reach the hypothetical stage in which it might ape the immature condition, one would expect to find the latter in the largest instead of, as is here the case, in nearly the smallest specimens. Eleven or twelve inches is a far larger size than that at which many dabs spawn for the first time; but this is of little importance, since some are quite immature up to 9 inches during the spawning season, and, from the rapidity of growth which Cunningham has demonstrated in the species, we can understand that a fish which fails to reach the required standard, whatever it be, at the time of year favorable to the maturation of the reproductive organs, will materially increase in length before the opportunity again presents itself.* Apart from this I do not see how it is possible for the ovary to shrink to such an extent. It would involve the atrophy of the greater part of the ovarian substance, and there is no evidence

* Probably the growth will be more rapid than in a mature fish, since there will not be the same drain on the resources of nutrition for the development of the sexual products. 
of such a process. I have certainly met with an instance of atrophy of the ovaries in another species, but it was evidently of a pathological nature, and conducted along lines which seemed very unlikely to result in a simulation of the immature condition (vide p. 382).

To recapitulate, I would state that when retained ova are not present to place the matter at once beyond doubt, a spent can always be distinguished from an immature ovary by the wide flaccid anterior region, by the greater length of the posterior process, * and by the loose manner in which the latter is lodged in the cavity alongside of the hæmal spines. Indeed, if the specimen is fresh, a groove, which can be felt by passing the finger along the skin in this region, is almost a sufficient test; but if the fish is more or less stale, the groove is to some extent perceptible even in immature fish.

The members of group (b), viz. the common sole, lemon sole, and witch or pole dab, present rather more difficulty, as there is never any great dilatation of the anterior part of the ovary, and its posterior process is more or less elongated from a rather early period. In soles of three or four inches, and in lemon soles of six inches (the smallest I have been able to procure), it is already considerably developed. Moreover in all forms the backward extension of the gut on the ocular side prevents any constriction of the corresponding ovary by the caudal muscles; and in the case of the sole the same effect is attained on the blind side by the disposition of the hind part of the kidney and the urocyst. In the lemon sole and pole dab the ovary is the only occupant of the cavity on the blind side of the hæmal spines ; yet in the former it is but little occluded by connective tissue in the posterior region at any period, whilst even the anterior part, which is so firmly fixed by the caudal muscles in immature members of group $(a)$, is always comparatively loose. I have not been able to examine enough small pole dabs to know whether the same holds good for that species also, but I believe it is the case.

A recently spent ovary can, of course, be easily detected as such by the nature of the germinal epithelium, and usually by the presence of retained ripe ova. Thus in the sole the degenerating follicles, deeply coloured by hæmoglobin, are very conspicuous, much more so than in any other species I have studied. Again, ova which have passed the inactive condition have been present in all spent ovaries which I have examined, and entirely absent from specimens I have considered to be immature. The ovary itself is also longer and wider, and flaccid anteriorly in the former condition, and narrow, plump, and rounded in the latter, but more conspicuously so in the sole than in the lemon sole. The length is a matter of comparison; thus in the sole I have not found immature ovaries to exceed two

* This is, of course, a matter of comparison, according to the species. 
fifths of the distance from the first hæmal spine to the caudal peduncle, whilst spent ovaries have always been longer. It is as yet too early to summarise the proportional differences in the lemon sole, as the spawning period is apparently very protracted in individuals as well as in the species; but it seems that a spent ovary is always wider and longer than an immature one. Nor is it yet possible to ascertain to what extent the shrinkage of a spent ovary is carried, either in the sole or in the lemon sole, or whether, by the absorption of the small active ova, an entirely inactive germinal epithelium is ever met with in spent examples. Should this occur, and no retained ova be present, it would be extremely hard to distinguish the condition in a lemon sole. An instance, which I suppose to be exceptional, of the degeneration of a spent ovary has come under my notice in the sole. The wall of the posterior portion of either ovary had become disintegrated, and fragments of the germinal epithelium had consequently found their way into the general cavity which lodges the ovary, whilst on the blind side similar matter, containing both active and inactive ova, had penetrated between the muscles of the interhæmal ridge and between the bases of several of the anal fin-rays and the skin. I suppose that this process of atrophy would in time have extended to the rest of the ovary, but clearly it would not result in any condition resembling that of an immature example.

It need hardly be said that when an ovary agrees with the immature condition in other respects, but exhibits an activity in the germinal epithelium, it is reasonable to suppose that the fish is about to spawn for the first time. Thus the distinction between an ovary ripening for the first time and for any subsequent time is not hard, so long as it is only in the early stage of maturation. The difficulty is felt when the organ has attained a considerable development, such as would, in the case of a fish that had already spawned, suffice to obliterate the traces by which such condition might otherwise have been recognised.

It has been difficult, notably in the case of the turbot and brill, to obtain sufficient numbers of females at the critical sizes, since amongst the smallest members of any species brought to market the males are always infinitely more numerous than the females; the converse, of course, holding good amongst the larger examples, which are of less interest for the purpose in hand. The accompanying figures must not be taken as indicating the relative abundance of the sexes at the different sizes, since, in selecting fish for examination, I have often had to reject large numbers of males, from want of time for the record of their condition.

I may here remark that, according to my experience, whenever a catch of fish from an offshore ground, especially in the spawning 
season, includes both large and rather small fish-say from the full size down to the smallest size of mature males, - the limit of size which divides mature from immature females will be found to practically separate the two sexes. Thus most of the larger fish will be mature females, and most of the smaller ones will be mature males, with a sprinkling of immature members of both sexes. This is in complete accord with Fulton's observations on the distribution of fish on the spawning grounds (Rep. S. F. B., 1890, 178), and it is noteworthy as an impediment in the way of the rigid application of a size limit based on the condition of the larger sex. But it is not of the highest importance, since the number of small fish in such cases is, by comparison, insignificant (thus following the well-known proportionate abundance of the sex), and it is only applicable to such species as show a marked change of habitat in apparent relation to the spawning instinct, and is variable within the limits of a species according to locality. *

Local Variation.-A comparison of the results obtained by work on the different coasts of Great Britain suggests a speculation on the rate of growth in relation to maturity.

Thus I understand from Messrs. Calderwood and Cunningham that at Plymouth the plaice spawns at about 10 inches, a marked contrast to the North Sea or even the west of Ireland conditions. Again, Cunningham has found mature lemon soles (supra, No. 3, p. 244) about as small as any which I met with on the west of Ireland. With regard to the common sole, the limit proposed for this district and for the west of Ireland is held by Mr. Calderwood to be equally applicable to the Plymouth district, whilst Mr. Cunningham would put it only a trifle lower.

Now soles appear to be much the same size on all three coasts, lemon soles are much larger in the North Sea than in the other districts, and according to Cunningham (supra, No. 2, p. 100) plaice are much smaller at Plymouth than in the North Sea. West of Ireland plaice appear to be intermediate in size, but in this respect approach the North Sea rather than the Plymouth fish, though, as I had not much material on which to base my Irish limit for this species, this is not of much importance.

We see, therefore, that where there is agreement in the size of fish of a species in any two or more districts, there appears also to be agreement in the size at which sexual maturity is reached, and that when there is variation maturity is reached at the smallest size in the district where the species is smallest.

* E. $g$. it appears to apply to turbot on the Dogger, whilst on the eastern grounds spawning and immature turbot may be caught together, the latter far exceeding the former in number. 
We are aware, from Cunningham's researches on the rate of growth, that this varies with the size in different species; and from the remarks of the same author on the plaice (supra, No. 2, pp. 99, $100)$ it appears that the same principle is applicable to local variation of size within the limits of one species. Hence it would appear that local variation in the size at which sexual maturity is reached is explicable by, or implies, variation in the rate of growth, and involves no local difference in the age* at which fish spawn for the first time.

Size Limits for the North Sea District.-The following measurements are intended to represent the average sizes at which the female spawns for the first time in the North Sea district, so far as such are ascertainable from observations made during, shortly before, or soon after the spawning season:

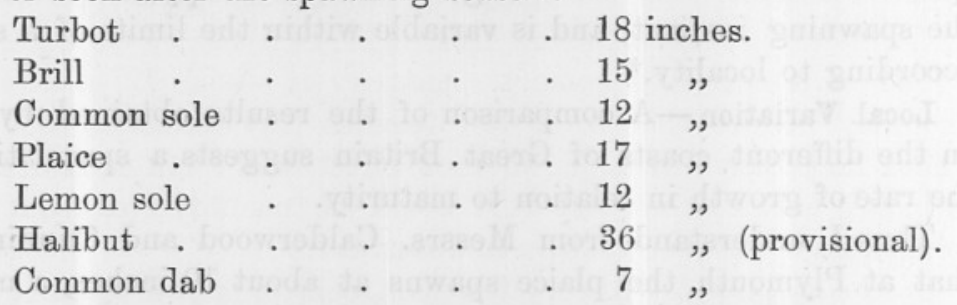

I have not paid much attention to the common dab (Pleuronectes limanda); the smallest ripe female I have seen measured 6 inches, and the largest immature female, during the spawning season, 9 inches. Flounders (P. flesus) and long rough dabs (Hippoglossoides limandoides) have not been available in sufficient numbers for a satisfactory conclusion. The same applies to the megrim (Rhombus megastoma), which is rather a rare fish on the grounds usually worked by Grimsby trawlers, and the witch ( $P$. cynoglossus); but it is worthy of note that twelve female witches of 12 and 13 inches and two of 14 inches were immature, whilst one of 14 inches was three parts ripe. Hence it seems likely that the fish does not spawn at so small a size (12 inches) as on the west coast of Ireland. I have never seen a sand or lemon sole (Solea lascaris), and only one solanette (S. minuta) and scald-fish (Arnoglossus laterna) in the Grimsby district. None of the remaining British Pleuronectids, the topknots, have been met with.

The following tables are abstracted from my records, and comprise only the fish at the critical sizes examined between the dates specified. It will be understood that all larger fish examined were found to be mature, the converse holding good in the case of smaller fish.

\footnotetext{
* Allowing for the individual variation in one locality which Cunningham has shown to
} exist in this feature (supra, No. 3, pp. 224, 225). 
Turbot (Rhombus maximus).

April 1st to September 12th, chiefly during the spawing period.

\begin{tabular}{|c|c|c|c|c|c|c|c|c|}
\hline \multirow{2}{*}{ Length. } & \multicolumn{4}{|c|}{ MALE. } & \multicolumn{4}{|c|}{ FEMALE. } \\
\hline & $\begin{array}{c}\text { No. } \\
\text { examined. }\end{array}$ & $\begin{array}{l}\text { Ripe or } \\
\text { recently } \\
\text { spent. }\end{array}$ & $\begin{array}{l}\text { Approach- } \\
\text { ing } \\
\text { ripeness. }\end{array}$ & Immature. & $\begin{array}{c}\text { No. } \\
\text { examined. }\end{array}$ & $\begin{array}{l}\text { Ripe or } \\
\text { recently } \\
\text { spent. }\end{array}$ & $\begin{array}{l}\text { Approach- } \\
\text { ing } \\
\text { ripeness. }\end{array}$ & Immature. \\
\hline At 11 inches & 3 & 0 & 3 & 0 & 0 & 0 & 0 & 0 \\
\hline 12 & 14 & 2 & 11 & 1 & 2 & 0 & 0 & 2 \\
\hline $13 "$ & 39 & 13 & 24 & 2 & 15 & 0 & 0 & 15 \\
\hline 14, & 39 & 16 & 22 & 1 & 45 & 0 & $2 *$ & 43 \\
\hline 15 & 25 & 13 & 12 & 0 & 41 & 0 & 6* & 35 \\
\hline 16 & 42 & 23 & 19 & 0 & 14 & 0 & $1 \%$ & 13 \\
\hline 17 & 73 & 50 & 23 & 0 & 25 & 0 & 13 & 12 \\
\hline 18 , & 78 & 54 & 23 & 0 & 28 & $2 \dagger$ & $12 \ddagger$ & 14 \\
\hline 19 & 60 & 46 & 14 & 0 & 36 & 8 & $27^{+}$ & 1 \\
\hline 20 & 33 & 22 & 11 & 0 & 68 & 22 & 45 & $1 \S$ \\
\hline
\end{tabular}

The male seems to come to maturity at about 12 to 15 inches. Though I believe that some few females may spawn at 17 inches, I have no positive evidence to that effect, and I am convinced that 18 inches is the lowest size that could be usefully employed in defining a limit between mature and immature.

Spawning period.-A very few fish seem to spawn as early as the end of March, and a few during April. Spawning becomes more general towards the end of May. The chief period is June and July. The number of ripe females diminishes throughout August, but a few do not finish spawning until early in September.

Brill (Rhombus lævis).

April 1st to June 30th.

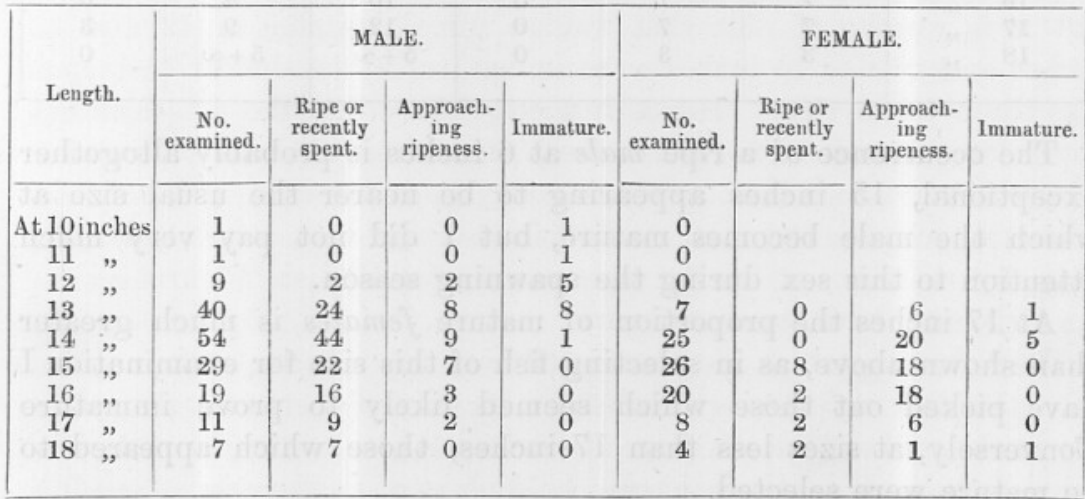

* Reproductive organs very little advanced.

+ Exact size, $18 \frac{1}{2}$ inches.

$\ddagger$ One three parts ripe, the rest half ripe.

$\S$ Examined after the spawning period. 
It appears that the male is mature at from 12 to 15 inches, as in the turbot, but probably some smaller specimens, if procurable, would be found mature.

The margin of variation in the size at which the female first spawns appears to be rather more narrow than in most other species; but it was impossible to obtain small females in sufficient numbers.

Spawning period.-Spawning appears to commence in the latter part of April, and becomes general by the beginning of May. It is continued throughout that month and the early part of June, after which it diminishes, and is practically over by the end of July. The spawning period is thus much the same as that of the common sole.

\section{Plaice (Pleuronectes platessa).}

From February to June, the larger fish chiefly during the spawning season.

\begin{tabular}{|c|c|c|c|c|c|c|c|}
\hline \multirow{2}{*}{\multicolumn{2}{|c|}{ Length. }} & \multicolumn{3}{|c|}{ MALE. } & \multicolumn{3}{|c|}{ FEMALE. } \\
\hline & & No. examined. & Mature.* & Immature. & No. examined. & Mature.* & Immature. \\
\hline \multicolumn{2}{|c|}{ At 6 inches } & 1 & 1 & 0 & 3 & 0 & 3 \\
\hline 7 & ," & 5 & 0 & 5 & 7 & 0 & 7 \\
\hline 8 & , & 37 & 0 & 37 & 43 & 0 & 43 \\
\hline 9 & ” & 98 & $3 \dagger$ & 95 & 114 & 0 & 114 \\
\hline 10 & " & 71 & $1 \dagger$ & 70 & 73 & 0 & 73 \\
\hline 11 & " & 33 & 0 & 33 & 36 & 0 & 36 \\
\hline 12 & , & 15 & 0 & 15 & 27 & 0 & 27 \\
\hline 13 & , & 12 & 3 & 9 & 23 & 1 & 22 \\
\hline 14 & " & 14 & 7 & 7 & 19 & 0 & 19 \\
\hline 15 & ", & 5 & 3 & 2 & 21 & 6 & 15 \\
\hline 16 & ” & 7 & 7 & 0 & 10 & 4 & 6 \\
\hline 17 & " & 7 & 7 & 0 & 12 & 9 & 3 \\
\hline 18 & ", & 3 & 3 & 0 & $5+\sim$ & $5+\sim$ & 0 \\
\hline
\end{tabular}

The occurrence of a ripe male at 6 inches is probably altogether exceptional, 15 inches appearing to be nearer the usual size at which the male becomes mature, but I did not pay very much attention to this sex during the spawning season.

At 17 inches the proportion of mature females is much greater than shown above, as in selecting fish of this size for examination I have picked out those which seemed likely to prove immature Conversely, at sizes less than 17 inches, those which appeared to be mature were selected.

At 18 inches I have seen in the market numbers of evidently

* Nearly ripe, ripe, or spent, except $\dagger$ in which the reproductive organs very little advanced. 
mature fish, and am convinced that percentage of immature at that size during the spawning season is infinitesimal.

A female of 19 inches was found to be immature, but this was some months after the spawning season.

Spawning period.-From the middle of January to the end of March, but some seem to spawn in April, and a few perhaps as late as May. It seems probable that spawning also takes place to some extent earlier in the winter, but of this I have not yet sufficient vidence.

Common sole (Solea vulgaris).

From February to September 12th, chiefly during the spawning season.

\begin{tabular}{|c|c|c|c|c|c|c|c|c|}
\hline \multirow{2}{*}{ Length. } & \multicolumn{4}{|c|}{ MALE. } & \multicolumn{4}{|c|}{ FEMALE. } \\
\hline & $\begin{array}{c}\text { No. } \\
\text { examined. }\end{array}$ & $\begin{array}{l}\text { Ripe or } \\
\text { recently } \\
\text { spent. }\end{array}$ & $\begin{array}{l}\text { Approaeh- } \\
\text { ing } \\
\text { ripeness. }\end{array}$ & Immature. & $\begin{array}{c}\text { No. } \\
\text { examined. }\end{array}$ & $\begin{array}{l}\text { Ripe or } \\
\text { nearly } \\
\text { spent. }\end{array}$ & $\begin{array}{l}\text { Approach- } \\
\text { ing } \\
\text { ripeness. }\end{array}$ & Immature. \\
\hline At 6 inches & 0 & & & & 2 & 0 & 0 & 2 \\
\hline 7 & 4 & 0 & 0 & 4 & 3 & 0 & 0 & 3 \\
\hline $8 "$ & 29 & 1 & 3 & 25 & 45 & 0 & 0 & 45 \\
\hline $9 \quad "$ & 28 & 4 & 13 & 11 & 66 & 0 & 0 & 66 \\
\hline 10 & 38 & 15 & 22 & 1 & 28 & $1 *$ & 8 & 19 \\
\hline $11 \%$ & 33 & 6 & 24 & 3 & 26 & 0 & 14 & 12 \\
\hline $12 "$ & 9 & 2 & 7 & 0 & 33 & 3 & 26 & 4 \\
\hline $13 \%$ & 7 & 3 & 4 & 0 & 18 & 2 & 16 & 0 \\
\hline $14 \quad$ & 3 & 2 & 1 & 0 & 10 & 4 & 6 & 0 \\
\hline
\end{tabular}

Ten inches appears to be the usual size at which the male reaches maturity.

Though, as appears above, a female may occasionally spawn at $10 \frac{1}{2}$ inches, I am convinced that comparatively few spawn at less than 12 inches, and I have no evidence of immature fish at more than 12 inches during the period of observation.

Spawning period.-Ripe females begin to appear at the end of April, and are abundant during May and June, which seems the chief spawning time. They become scarcer during July, and spawning is practically over by the early part of August.

Spent females begin to appear in the Humber at the beginning of July, and become more numerous as the month goes on, and continue to abound during August and the early part of September.

* Exact length, $10 \frac{1}{2}$ inches. 
Lemon sole (Pleuronectes microcephalus).

February to September, chiefly during the spawning season.

\begin{tabular}{|c|c|c|c|c|c|c|c|c|}
\hline \multirow{2}{*}{ Length. } & \multicolumn{4}{|c|}{ MALE. } & \multicolumn{4}{|c|}{ FEMALE. } \\
\hline & $\begin{array}{c}\text { No. } \\
\text { examined. }\end{array}$ & $\begin{array}{l}\text { Ripe or } \\
\text { recently } \\
\text { spent. }\end{array}$ & $\begin{array}{l}\text { Approach- } \\
\text { ing } \\
\text { ripeness. }\end{array}$ & Immature. & $\begin{array}{c}\text { No. } \\
\text { examined. }\end{array}$ & Ripe. & $\begin{array}{l}\text { Approach- } \\
\text { ing } \\
\text { ripeness. }\end{array}$ & Immature. \\
\hline At 6 inches & 1 & 1 & 0 & 0 & 2 & 0 & 0 & 2 \\
\hline $7 \quad$ & 20 & 10 & 4 & 6 & 22 & 0 & 0 & 22 \\
\hline 8 & 12 & 10 & 1 & 1 & 22 & 0 & 1 & 21 \\
\hline 9, & 39 & 29 & 10 & 0 & 34 & 0 & 9 & 25 \\
\hline 10 & 60 & 56 & 4 & 0 & 51 & 3 & 24 & 24 \\
\hline 11 & 41 & 31 & 9 & 0 & 47 & 1 & 22 & 24 \\
\hline 12 & 23 & 20 & 3 & 0 & 14 & 1 & 12 & 1 \\
\hline 13 & 11 & 9 & 2 & 0 & 10 & 2 & 8 & 0 \\
\hline $14 \quad$ & 5 & 5 & 0 & 0 & 10 & $7 *$ & 3 & 0 \\
\hline
\end{tabular}

It appears that the male may be mature at 6 inches. No smaller specimens of either sex could be procured.

I do not think that many females spawn at less than 12 inches, though, as appears above, some spawn when only 10 inches in length.

Spawning period.-Ripe females first appear in the latter part of April ; they are abundant in May, more so in June and July. No spent females were met with until the latter part of August, although search was constantly made for them. Many fish are still spawning in the early part of September.

The protraction of the spawning period is evidently due to the fact alluded to elsewhere (p. 368), that the ova of a single individual are produced in successive crops in one season, separated from each other by an unusually great interval of time.

\section{Halibut (Hippoglossus vulgaris).}

More of my material was derived from Iceland and Faroë than from the North Sea. I know very little about the spawning period. Parnell gives the spring for the coast of Scotland. Grimsby liners seem to know very little of it, and are divided in opinion ; one of my informants thought he had seen spawning fish in April, but the general opinion seems to be that spawning does not take place until autumn or early winter. Probably, since the halibut is mainly a line fish, very few ripe females come under the notice of fishermen. Ripe males seem to occur more or less at all seasons of the year.

The only fully ripe female which I have seen occurred at the end of April. Another female, with enlarged ovaries, was found to

* One of these recently spent. 
contain a few ripe ova at the end of August. The condition of other large females at about the same time and in the early part of September seems to indicate that some spawning will take place in the autumn, on the Iceland grounds, at any rate. Very likely, as in the case of the haddock, the North Sea fish spawn earlier, but of this I have no evidence.

The fish enumerated below were examined at various dates between February and September (inclusive); and do not take into account a number of large fish which I have looked into from time to time, in the hopes of finding ripe ova.

Owing to the large size and high price of halibut, their purchase in any considerable number was out of the question. I have, therefore, had to depend, for the most part, on eye observations made in the market, checked so far as possible by the careful examination of a limited number in the Laboratory. In the case of females, the method of observation is indicated in the accompanying figures.

Total number of fish examined, 150 ; males, 64 ; females, 86.

Males.-Immature. -1 at 15 inches, 2 at 16,1 at 19,1 at 20, 2 at 21,2 at 22,1 at 28 , and 1 at 29 .

Approaching ripeness. -1 at 24, 1 at 25, 1 at 27, 1 at 28, 6 at 30, 4 at 31,4 at 32,2 at 33,4 at 34,3 at 35,1 at 36,3 at 37,1 at 38 , and 9 from 34 to 37 .

Ripe.-1 at 31,1 at 37,1 at 38,1 at 41 , and 2 over 50 .

Spent. -1 at 30,1 at 31,1 at 33,2 at 34 , and 1 at 35 .

It appears, therefore, that the male may be mature at about 30 inches, and is probably never mature at less that 25 inches.

Females.-Immature.-2 at 14 inches, 1 at 16, 2 at 24, 2 at 30, 1 at 31, 2 at 32, 1 at 33, and 1 at 35 . Examined in the Laboratory.

Immature, or very little advanced towards maturity.- 4 at 28 , 1 at 29,3 at 30,2 at 32,5 at 33,4 at 34,4 at 35,3 at 36,2 at 37 , 3 at 38,1 at 39,1 at 40,2 at 41,2 at 42,1 at 44,1 at 47,1 at 49 , 11 from 37 to 47 . Examined in the market.

Approaching ripeness, ovaries distinctly enlarged..-1 at 43, 1 at 45,1 at 49,1 at 50, 1 at 56, 1 at 59, and 15 over 60 . Examined in the market.

Ripe. -1 at 73 inches.

The inference is that, if the observations made in the market are approximately correct, the female does not spawn until she is about 4 feet long; but I would prefer to await the results of continued work in the later months of the year, and to make use, pro tem., of a limit of only 36 inches. 


\section{On the Destruction of Immature Fish in the North Sea.}

Introductory.-The subject has unfortunately become so familiar in recent years that it is unnecessary for me to refer, except very briefly, to its previous literature. The most important contributions have been those by Professor McIntosh, in the Report of the Trawling Commission, 1884, by Dr. Wemyss Fulton in the Annual Reports of the Scotch Fishery Board, 1890 and 1891, and by Messrs. Bourne and Cunningham in previous numbers of this Journal. I have contributed what information I could collect during the Royal Dublin Society's survey on the west coast of Ireland in the Scientific Proceedings of that Society, 1892, pt. 4, and at the recent meeting of the British Association the subject was dealt with in a joint paper by Mr. Calderwood, Mr. Cunningham, and myself.

In the present paper I have attempted to put in as brief a form as possible the information collected during the Association's investigations in this district, together with suggestions as to what appear to me to be the best methods of remedying the evil.

The methods of fishing in use by boats from Grimsby and its neighbourhood are as follows:

i. Beam-trawling, by steam and sailing smacks, from 60 to 100 tons each.

ii. Long-lining by similar vessels.

iii. Shrimp-trawling by small sailing vessels in and about the Humber estuary.

Other vessels are employed in the deep-sea oyster fishery, and a certain number of small boats are engaged in whelking.

The following shore fisheries are carried on along the southern shore of the Humber below Grimsby :

i. Stake-netting.

ii. Ground-seining.

iii. Shove-net shrimping.

iv. "Seine" shrimping.

I propose to glance very briefly at each of the above industries in so far as they are concerned in the destruction of immature fish.

Beam-trawling.-The conclusion arrived at by Mr. Bourne, as a result of observations made in the Plymouth district, was that no material damage was done by the above industry (supra, vol. i, No. III). Such is certainly not the case in the North Sea district.

From my own experience on board of trawling vessels on most of the North Sea grounds, and from the recorded observations of a number of trawling skippers, who have been kind enough 
to assist me in this matter, I find that a certain proportion of immature fish of valuable species are taken in almost every haul, whilst on certain grounds lying to the eastern side of the North Sea the catch consists almost entirely of immature plaice. This fact is only too well known to every one connected with the industry in this district; and has given rise to the periodical fishery conferences with which we are familiar.

At the same time I am not aware that any statement of the actual quantity of small fish which is destroyed on these grounds has ever been put forward, nor am I in a position to do so, since it is impossible to estimate the amount that is shovelled overboard, dead or dying, as failing to reach even the very modest standard of market requirements. I can, however, give the number of boxes which have been landed at Grimsby during the present season, containing only small fish. I am using the word "small " not in the biological sense, so as to include all sexually immature fish, but in the sense in which it is used by fishermen and others connected with the trade, so that it may be taken that the fish here enumerated are immature in every sense of the word. Very few of them are as much as 15 inches long, whilst in most boxes none exceed and few reach a length of 14 inches, the majority being from 7 to 13 inches in length. Boxes which, while containing a few fair-sized fish at the top, consisted otherwise of under-sized fish, are not included in the list.

There were landed at Grimsby-

In April, 1836 boxes of small plaice.
"May, 830 ", ",
"June, 3470
" July, 2059
", August, 1924 "

Total number of boxes for the five months, 10,119 .

It is probable that the number is actually greater, as some boxes may well have escaped my notice; at any rate, the number is not exaggerated.

Such boxes as I have counted contained about 300 fish, but probably some contain less when the larger fish are picked out and packed separately. We shall be well on the safe side in taking 250 as the average number, which gives us a total of $2,529,750$, or, in round numbers, two and a half million fish.

It must be remembered that these figures represent only the fish landed at Grimsby. During the present year only a single small fleet, about twelve sail, has been working the small fish grounds from Grimsby, most of the smack-owners having given orders to their boats to keep away from them. So far as I know, only one steam 
trawler has visited them with any regularity, though a good many others have been making occasional trips there. The balance of boats bringing in small plaice has been made up by a certain number of smacks "single-boating," and sticking with more or less regularity to the eastern grounds. Now from Hull alone two fleets, each exceeding 200 sail, have this year visited the small-fish grounds, as has also the combined Yarmouth, Lowestoft, and Barking fleet, but as to how long they remained there $I$ have at present no information. Steam trawlers have also been "across" from Hull and Boston. As the Board of Trade statistics do not discriminate between large and small fish of a species, I do not know how we can arrive at an accurate knowledge of the total number of small fish landed at all ports ; but I think that there is sufficient evidence, from the results achieved by the small number of Grimsby vessels, that it must have been enormous. The small fleet alluded to is still on the same ground.

Space does not permit me to enumerate the different grounds frequented by these small plaice in any detail. Briefly, they extend along the coast of Holland, Hanover, and Denmark, as far north as the Horn Reef, and from thence to Hantsholm on the coast of Jutland. They derive their names in most part from those of the islands nearest to them, strangely transformed in some instances by British pronunciation. They differ considerably in the quality of the fish produced, some grounds yielding none which are too small for market, others yielding more unmarketable than marketable fish, whilst north of the reef some grounds which seem to produce only small fish in the summer yield fine catches in the autumn.

There is no doubt that nearly all the plaice which are too small for market are, nevertheless, destroyed, not wantonly, perhaps, but simply because the exigencies of the fisherman's business do not permit of much attention being paid to any but marketable fish, even if the rest are not fatally injured by the pressure exerted by the large catches usual on these grounds before ever they reach the deck.

Plaice are not the only sufferers on these grounds, as large numbers of immature turbot are also destroyed. So far as I can gather from observations on the total number in the market on various days previous to the opening of the season for the grounds referred to, the proportion of immature turbot does not exceed 30 per cent., but once the boats begin to go "across" it rapidly rises. This is easily accounted for when we examine the catches from the eastern grounds.

Thus in May a steam trawler from the Borkum ground landed 216 turbot in two trips. Of these only six were above 17 
inches, * whilst in one of the trips, when 105 fish were caught, no less than 68 were under 13 inches.

During June the aggregate of thirty-one trips of steam and sailing vessels from the Dutch, German, and Danish coasts was 4623 turbot, of which 786 were mature and 3837 immature. The proportion of immature is thus 82 per cent. The highest proportion reached in individual cargoes is 100 per cent., and the lowest 28 per cent., but only in two instances does it fall below 50 per cent.

During July, eighteen trips comprised 2435 fish, the proportion of immature being 69 per cent., a diminution since the previous month, which is probably explicable by the fact that the body of the plaice on which the fishing chiefly depends had shifted from the inshore part of the grounds, which seems most frequented by young turbot.

It has been asserted that many immature brill are destroyed on the same grounds, but of this I can find no evidence. In fact, the brill seems rather scarce on the eastern side of the North Sea, and nearly all which I have seen brought in from thence have been sexually mature. Fishermen and fishmongers are apt to class turbot and brill alike in discriminating between large and small, which may account for the assertion I have alluded to. Brill of less than 15 inches reach the Grimsby market chiefly from about Mablethorpe, on the Lincolnshire coast, where they seem rather plentiful.

The common soles which are taken on the eastern grounds by our trawlers seem nowadays to consist chiefly of mature fish. One hears a great deal of the destruction of small soles in former years, but it appears that the boats at that time went much closer to the shore than they dare to go at present.

As may be supposed, young lemon soles and witches or pole dabs are not found on these grounds. The flounders there met with are mostly of fine size. A young halibut is sometimes taken, and common dabs of all sizes abound.

In the North Sea halibut are not usually caught in large numbers in the trawl, but in the spring I have occasionally seen large catches brought in. These consisted almost entirely of small fish, and, according to my information, were chiefly derived from the South-west Flat of the Great Fisher Bank. The trawlers that have visited the Iceland grounds this summer generally brought in only a few small halibuts, but the number was sometimes considerable when they had been fishing a ground known as Madam Piper's Bay, near Langenness.

* In dividing mature and immature turbot I made use of this limit of size, believing then that it represented the limit of sexual maturity in the female, which I have since found to be somewhat higher.

NEW SERIES.-VOL. II, NO. IV. 
Considerable numbers of small round fish, chiefly haddock, skates, and rays, are taken on various North Sea grounds, but I do not propose to discuss this matter at present.

Long-lining.-Besides the larger skates, the only species which in its immature condition is a considerable sufferer from this method of fishing appears to be the halibut. I believe that not less than half the halibut which are brought ashore here fail to reach even the provisional standard of maturity which I have proposed elsewhere, but I have not determined the proportions with exactness. The smallest fish which I have seen landed by liners measured 15 inches, a size which, proportionally to that of the species, is less than that of the smallest plaice landed by trawlers from the eastern grounds. The matter can be better dealt with when more exact knowledge of the relation of size to maturity has been arrived at.

I understand that young coal-fish, in the "sillock" stage, are caught by liners in the Orkney and Shetland harbours for use as bait, but as the species is not of great value the proceeding seems perfectly justifiable.

Shrimp-trawling.-This industry is carried on by one boat of 22 tons, five from 15 to 18 tons, and nine from 8 to 11 tons, these last being known as "prawners." All carry similar gear, viz. a trawl of shrimp-mesh not exceeding 20 feet in beam. The larger boats were formerly in the habit of also carrying small fish-trawls or "sole-nets," but a bye-law of the Eastern Counties Fishery Committee now prohibits the use of fish-trawls in the Humber, and only permits the use of shrimp-trawls from the beginning of April to the end of September. No machinery exists to enforce this law, and I understand that, so far as the use of fish-trawls is concerned, it is generally evaded. However, as the fish brought to market by these boats purport to have been caught only in shrimp-trawls, they may be dealt with under this head. They consist of common soles, plaice, and flounders, with a few common dabs. Turbot, brill, and lemon sole are only rarely met with.

Soles are never brought to market in very large numbers, fifty or sixty pairs being considered a very fine haul for one boat in a night, but up to the latter part of June almost all the fish are under 12 inches, and sexually immature, whether males or females, so far as I can judge from the examination of a considerable number. Towards the end of June larger spent fish appear to find their way into the Humber from the off-shore grounds. Thus in the early part of June, of 126 fish 112 were under-sized, but on the last day of that month 242 fish, representing the catches of two boats, included 40 above 12 inches, some of them very fine fish. The smallest soles brought to market are from 6 to 7 inches long, any 
smaller ones caught being promptly returned. During the succeeding months the proportion of large fish rather increases, but the smaller ones always largely predominate.

Plaice and flounders are sold together. The former, which never reach any great size during the time they remain in the Humber, are considered by the Cleethorpers, who used to monopolise the Humber fisheries, to be a distinct species, which they call flat-fish or fluke. They consider that the gelatinous egg-capsules of certain Polychætes are the spawn of these fish. As in the case of the sole, very small plaice or flounders are returned by the shrimp-trawlers to the sea. Those brought ashore measure from about 6 inches up to about 11 inches. I found a box of Humber flat-fish to contain 425 plaice, from 6 to 11 inches, averaging in length $7 \cdot 71$ inches, and in weight $\cdot 18 \mathrm{lb}$., and 34 flounders from 5 to 13 inches. The total amount sold in the market from the beginning of the season to the end of July appears to be something under 300 boxes, and thus not more than a steam trawler will sometimes bring in from the Dutch coast in a single trip.

Numbers of small whiting and cod are sometimes caught, especially the former. I have received 254 whiting, from $2 \frac{5}{8}$ to $4 \frac{15}{16}$ inches, and 16 cod, $2 \frac{3}{8}$ to $3 \frac{7}{8}$ inches, from one boat, but they are not usually brought ashore, though the whiting, even if immediately returned, would probably not survive.

Shore Fisheries: Stake-netting.-There are only two stake-net stations below Grimsby, viz. one at Cleethorpes and one at Humberstone. Both nets are owned by the same man, a resident of Cleethorpes, and, as I understand, have not been very productive during the present year.

The mesh is 1 inch from knot to knot, or $\frac{1}{2}$ inch square, and the nets are intended for the capture of sprats or smelts according to the season. The Cleethorpes net was only up for about a month in January and February, but the Humberstone net remained in use until April. I examined a week's catch, in the latter net, at the end of January. It consisted of a large basket of sprats, 2 to $5 \frac{1}{4}$ inches, but mostly about $3 \frac{1}{2}$ inches; less than half a stone of small herring, locally termed "scad," $5 \frac{1}{4}$ to $7 \frac{3}{4}$ inches ; about 300 whiting, 4 to $7 \frac{1}{2}$ inches; 14 plaice, $1 \frac{3}{4}$ to $7 \frac{1}{2}$ inches, and a few other fish of less important species. These were removed from the net and carted up to the house, where the saleable fish were sorted out, the rest being used for manure. Later in the season I am informed that large numbers of small cod and whiting were taken in the Humberstone net, but I had not another opportunity of inspecting the catch.

Ground-seining.-Only two ground-seines are in use at Cleethorpes, and do not appear to be often worked. Eels, smelts, and plaice 
are taken in them, but only the larger plaice are kept, all small fish being allowed to escape. Thus, except that all Humber plaice are immature, there is no intentional destruction of undersized fish in this industry.

Shove-net Shrimping.-The hand shrimp-net in use along the Humber sands is a sufficiently formidable engine. It is shaped like the letter $\mathrm{T}$, the cross-piece representing the beam, which is 9 feet long, with a short iron upright at each end, while the shaft, represented by the body of the letter, is somewhat shorter. The lower end of the net, either sprat or shrimp mesh, is laced to the beam and uprights, the upper end being gathered on to an iron ring, which is drawn up the shaft by means of cords passing through the handle of the latter. In this way the belly of the net is made exceedingly rigid, and its meshes are almost closed, so that shrimps, \&c., slide right up it into a fine mesh bag or cod-end just below the ring.

There are a number of these nets in Cleethorpes, but most of them are not worked with any great regularity, as the incidence of the Cleethorpes "season," from Whitsuntide to September, brings other and more lucrative occupation to the owners. As a rule, however, a good many shrimpers go out every springtide, and some, engaged with pleasure-boats during the day, shove the net by night.

Great numbers of small fish are caught in these nets, and very many are undoubtedly destroyed, since the men are not always careful in sorting them out at the margin, but often carry the whole catch home; sorting by night is of course a difficult matter.

Small soles, turbot, and brill are usually promply returned if observed, and lesser weevers* enjoy an undeserved immunity, since their room is preferred to their company; but little " flat-fish," really plaice, are not held to be of much account.

The shrimps and small fish seem to accompany each other in approaching and leaving the margin, since a good haul of the former always involves a large number of the latter, and vice versâ. The minute metamorphosing stages of flat-fish are never found in this company, the smallest plaice and dabs which I have seen being about 1 inch long, and the smallest turbot, brill, and sole over 2 inches. As might be expected, the sizes vary with the season of the year, but not to any great extent ; and the following list, representing the catch of one net for one tide about the beginning of the season (25th April), is sufficiently representative of the conditions during the spring and summer.

* Injuries from this fish are not uncommon, probably because the fishermen, in their dread of the harmless anterior dorsal fin, pay no attention to the opercular spine. 


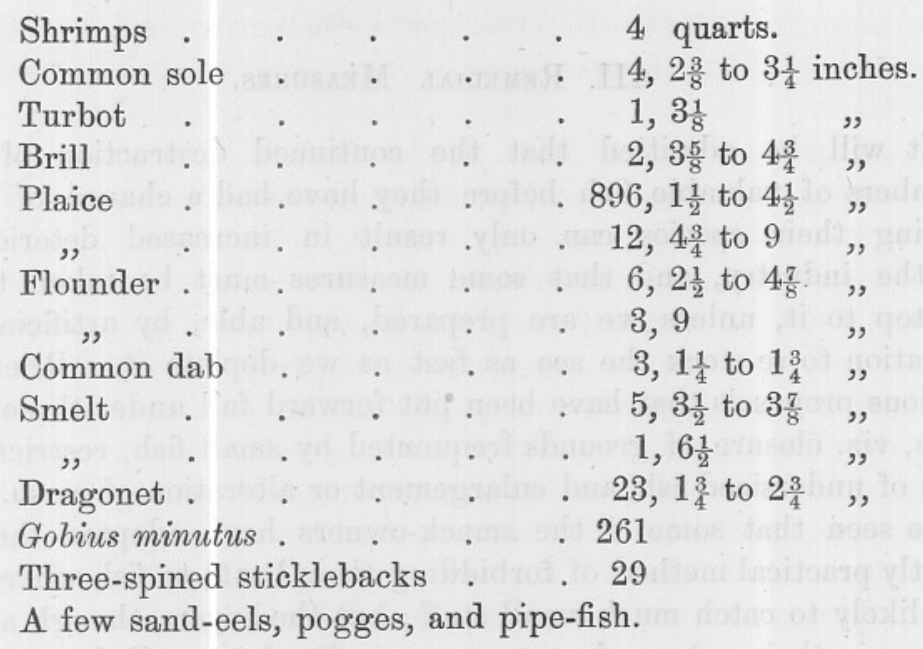

Dabs are sometimes rather more numerous, and occasionally a number of small whiting are taken. Cottius bubalis and young sprats are of frequent occurrence. Turbot, brill, and sole are never much more numerous. Towards the end of the summer one or two fine soles are sometimes taken. The catch always includes a number of shore-crabs, which are promptly returned, as they damage the shrimps in the net and basket.

It will be seen that the bulk of the injury falls on the plaice, and I need not say that the annual destruction of the young of this fish must be enormous. How far the prolonged existence of an insignificant fishery, so baneful to the objects of an industry of national importance, can be justified is a question that must be discussed elsewhere.

Shrimp-seining.-The shrimp "seine" of Cleethorpes is in reality a fine-mesh trawl, with a mouth about 18 feet wide, which is kept open by means of a pole. Two short wooden beams, heavily loaded at the lower end, serve to keep the wings upright, and to separate the head and ground ropes. The whole affair is attached by the bridles to the axletrees of a small one-horse trolley, driven by the fisherman, and might be better described as a cart-trawl.

Seven such "seines" are owned in Cleethorpes, and work the same grounds as the shove-nets, and as they differ from the latter only in being rather more efficacious, and thus making larger catches both of shrimps and of small fish, they may be classed in the same category. The only notable difference is in the method of disposing of the catch which in the present instance is shot wholesale into a box on the cart, and not sorted until the fisherman gets home. 


\section{Remedial Measures.}

It will be admitted that the continued destruction of large numbers of valuable fish before they have had a chance of reproducing their species can only result in increased deterioration of the industry, and that some measures must be taken to put a stop to it, unless we are prepared, and able, by artificial propagation to re-stock the sea as fast as we deplete it. Briefly the various proposals that have been put forward fall under three headings, viz. closure of grounds frequented by small fish, restriction of sale of undersized fish, and enlargement or alteration of mesh. We have seen that some of the smack-owners have adopted the eminently practical method of forbidding their boats to fish where they are likely to catch much small stuff ; but the buyers, though as loud as any in their outcry, do not appear inclined to avail themselves of their undoubted power to check the evil. The proposals for legislative action have been so much discussed of late that I need only advert to such as affect the North Sea district.

It is a matter of common knowledge that the bulk of the destruction by deep-sea trawlers takes place on the eastern grounds, to which I have alluded elsewhere; and since these lie wholly or in part outside the three-mile limit, it has been proposed that they shall be closed to trawling by international agreement. Whether such agreement could ever be arrived at is questionable; and if it were, it is not likely that the ensuing legislation could be easily enforced. The great extent of the grounds would involve an enormous and costly Marine Police force, of mixed nationality; and even were such a body much more efficient than one has any reason to expect, there might be considerable difficulty in adequately watching grounds which extend in some cases over fifty miles from shore. Indeed, on our own coasts and elsewhere the success with which legislation limited to the territorial area has hitherto been enforced is hardly such as to encourage us to extend the principle to the open sea.

The various standards of size which have been advocated, in proposals for prohibiting the sale or possession of undersized fish, differ according as the subject has been treated with regard to the marketable qualities of the fish, or to its powers of reproduction; and it may be assumed, I suppose, without argument that the latter is the more rational method of treatment. Still it may be as well to recapitulate the sizes proposed at the Fishery Conference at Fishmongers' Hall last February, since they may be taken to represent the most recent trade opinion on the subject. 
They are for turbot and brill 12 inches, for soles and lem on sole (Pleuronectes microcephalus) 10 inches, and for plaice 11 inches. How far they fall short of the biological limits, at least for the North Sea district, can be judged by comparing them with the table of sizes on p. 384; and, indeed, I may remark that the prohibition of the sale of turbot and brill under 12 inches in length is rather a work of supererogation, since the number of smaller fish of these species that come to market, at all events at Grimsby, is utterly insignificant.

The benefit to be expected from any measure of prohibition depends of course on the vitality of the fish, and it is very generally asserted that the bulk of the small fish trawled on these eastern grounds would not survive if returned. My own experience leads me to believe that this view is correct* so long as the present system of long hauls is maintained. Hence we must seek for such a limit as will render the grounds most frequented by these small fish unprofitable to the fisherman (since any less limit would only involve an infinitely greater waste than takes place at present), and in doing so it is necessary to glance at the general conditions of this fishery.

Exclusive of less important forms, the species chiefly met with are plaice, turbot, and soles. The plaice, on most grounds, do not exceed a length of 15 inches, and are mostly less than 13 inches in length. The turbot are fairly abundant, but, as I have already shown, almost all immature; soles are scarce. It is only the certainty of being able to fill up with small plaice that induces the fisherman to cross to the eastern side, since the soles and turbot would not nearly pay his expenses by themselves. Now I am confident that if the Conference limit of 11 inches for plaice were enforced, there would still be enough saleable fish left to make the grounds worth visiting, whereas if it were raised to 15 or even 14 inches the grounds would assuredly be left alone; and although such would be below the biological limit, I believe the practical closing to our huge fleets of such a magnificent nursery for young plaice would be in itself a sufficient protection for the species. Certain rough patches of ground, practically surrounded by areas yielding only small fish, abound with only large fish ; these would still be accessible to fishermen, whereas in any scheme of geographical restriction it would hardly be possible to exempt them. Moreover the restriction of size would probably do away with the destruction of small plaice by shrimp- or sole-trawls, since the fish are not injured

* Owing to the great mass of fish caught in a single haul, I consider it quite possible to hold this view without throwing any doubt on the value of the results obtained by my friend Dr. Fulton in his experiments on the vitality of trawled fish (Report S. F. B., 1891). 
by being caught in these nets, and if unsaleable* would probably be returned.

For turbot, brill, and sole I would advocate the adoption of the biological standards. They are all rather hardy forms, and it appears that immature brill and such immature turbot as are found on our own coasts are chiefly caught on certain banks where the intricate nature of the ground renders short hauls a necessity, so that they could be returned to the sea in good condition, as indeed the smaller of them usually are at present by many fishermen. With regard to soles, I do not think that many undersized fish are caught by deep-sea trawlers, $\uparrow$ and the substitution of a size limit for the present prohibition of the use of a fish-trawl in the Humber would do away with the anomaily of a law which is not enforced. There is a strong feeling amongst inshore fishermen that the bye-law alluded to is unequal in its operation, since it offers no check to the destruction of small fish on off-shore grounds, only accessible to large boats. Hence a regulation as to the size of fish landed is perhaps preferable to one based solely on territorial conditions somewhat imperfectly understood.

An objection which I have heard urged against any scheme for keeping our trawlers off the eastern grounds is that the summer sole trade in the North Sea would thereby be left entirely in the hands of foreigners. I think that this is, perhaps, rather overstating the case, but anyhow I cannot see that it furnishes any excuse for the present enormous destruction of small plaice and turbot, whilst it is at least possible that the abstention of our own fleet from these grounds in the summer would result in a corresponding increase in the number of soles in the localities where that species congregates in the winter months. I have no knowledge of the migrations of soles, but the Great Silver Pit is equidistant from the Humber and the nearest eastern ground, and as it is the nearest point at which similar physical conditions can be attained, it does not seem improbable that the winter supply of soles in the Pit is in part recruited from the east side of the North Sea.

Another objection is that boats of British nationality are not the only ones engaged in the small fish trade, and it is true that during the summer months a number of German, Dutch, and Danish boats are occupied in catching small plaice. But they are all of small tonnage, some of them only open boats ; and I understand that from

\footnotetext{
* The possession, as well as the sale, should be prohibited, to guard against the possible danger of small fish being utilised as manure when the fisherman is also a farmer in a small way.

† The small soles caught on the Dogger and on the Dowsing are really solanettes (Solea minuta).
} 
the manner in which the trawl is handled by German and Danish boats no injury is done to the unmarketable fish, whilst the saleable part of the catch appears to be exported chiefly to London. Hence the proposed measures of prohibition would give no advantage to these nations. The German steam trawlers, according to my information, do not molest the small plaice at all. Of the proceedings of the Dutch bombs I have little knowledge, but from the small size of their gear, their share in the destruction cannot be a very large one. Foreign-caught fish, except Norwegiun salmon and mackerel and Dutch soles, including only a small percentage of undersized fish, rarely come to the Grimsby market, but on two occasions large consignments of small plaice, comprising, as I compute, some 31,000 fish, were sent from Denmark, and recently a consignment of turbot has arrived from Norway. These last fish were about 300 in number, all undersized, viz. from $9 \frac{1}{2}$ to 17 inches, whilst 4 were only from 8 to 9 inches. This is the only instance which has come under my notice of any considerable number of turbot less than 12 inches being present in the market, and, as we have seen, our own fishermen were not concerned in it.

The last and perhaps the most important objection arises from the difficulty in allowing for that variation in the size of fish of the same species on different parts of our own coast to which Mr. Calderwood alluded in the last number of this Journal, p. 208. The impossibility of utilising a uniform size limit for all districts is sufficiently exemplified by the limit of 11 inches for the plaice proposed by the Conference of last February, which was the result of a compromise between the trade representatives of the North Sea and south and west coast districts. While perhaps unnecessarily high for the Plymouth district, we have seen that it is altogether too small for the North Sea. The difficulty of having different limits, of local application, will only be felt at such a central port or market as London, to which fish are brought, whether by rail or sea, from all districts, but with proper organisation the obstacle does not seem insuperable. It is conceivable that the law might be evaded by running cutters from boats fishing in one district to the parts of another, where the limit was lower, but it is little likely that the firms which are in a position to undertake them, would lend themselves to such operations. There is not the slightest reason to apprehend a general conspiracy of evasion amongst the fishermen, and the boats which respected the law would form a more efficient police than all the cruisers in the navy, so far as one may judge by the conditions on the Scotch coast, where convictions of trawlers for infringement of the territorial restriction are frequently secured by the evidence of local line fishermen. 
I must leave to others, who are acquainted with the local conditions, to decide whether the imposition of a size limit is desirable in other districts, but for the North Sea I have not the slightest hesitation in recommending this method of legislation, in the terms I have proposed above, as cheaper and likely to be infinitely more efficacious than any other that can be devised in maintaining the supply of the more important kinds of flat-fish. I need hardly observe that its application to the halibut, which is chiefly a line fish, could not fail to be beneficial to that species, since there is no question but that fish caught on the hook will usually survive if returned ; $*$ but I do not think that the limit need be as high as the biological one, owing to the difference in the conditions of the trawl and line fisheries.

I am not prepared to enter at present into the question of mesh legislation, beyond pointing out that it appears to be the only method by which the destruction of immature round fish, notably haddock and whiting, can be checked, since these species are fatally injured by being caught in the trawl, and would not survive if returned. Any great enlargement of the mesh does not appear advisable, since it would afford an opportunity of escape to the mature sole, of which that active species would be extremely likely to avail itself. The remedy seems to lie rather in an alteration of the arrangement of the meshes in the cod-ends, so as to prevent them from closing. On this subject I have been making investigations, but they are not yet sufficiently complete to yield reliable deductions. It is sufficiently evident, as has often been pointed out, that the great breadth of some of the flat-fish render it impossible to deal with the whole question by restrictions of mesh alone.

The last matter with which I have to deal is the destruction of very small fish by shove-net and shrimp "seines." If it were only possible to induce the men to cull out the small fish in the water they would do no harm at all, and practically I suppose that, as matters are, they do not greatly injure any species of known value except the plaice, although the small number of sole, turbot, and brill destroyed may represent, from the relative scarcity of these species, a more considerable injury than one would suppose. When fishing by day the shove-net men usually return the fish to the sea, but by night this is impossible, and the seine men do not seem to make any effort in that direction either by day or night.

It is a difficult question to deal with, since the shrimp appears to be almost a necessity to some people; at the same time the small plaice which are destroyed must represent an infinitely greater value than the shrimps. If hatcheries were established, and young turbot,

* Except fish with air-bladders, caught at considerable depths. 
brill, sole, and plaice were enlarged after they had been reared through the delicate larval and metamorphosing stages, it is reasonable to suppose that they would be conveyed or would find their way to the sandy margins, which seem best adapted to the succeeding stages of their life-history, only to fall into the net of the shrimper.

I should say that to prohibit the use of any sort of shore shrimpnet during night-time would be a beneficial measure, but there is perhaps sufficient reason for abolishing the industry altogether. Those engaged in it might be sufficiently compensated at a moderate expenditure, if indeed it be not contrary to public policy to admit the existence of a vested interest in an occupation which is essentially injurious to industries affecting a much greater section of the community. 